\title{
Heparin modulates intracellular cyclic AMP in human trabecular bone cells and adherent rheumatoid synovial cells
}

\author{
A. J. CRISP, M. S. ROELKE, S.R. GOLDRING, AND S. M. KRANE
}

From Harvard Medical School and the Medical Services (Arthritis Unit), Massachusetts General Hospital, Boston, MA 02114, USA

SUMmARY Cells were cultured from explants of human trabecular bone excised from eight patients and incubated usually for 20 minutes with bovine parathyroid hormone, salmon calcitonin, prostaglandin $E_{2}$, or heparin. The intracellular content of cyclic AMP was measured by radioimmunoassay and was significantly increased by parathyroid hormone in four, by calcitonin in two, by prostaglandin $\mathrm{E}_{2}$ in eight, and by heparin in seven out of eight cultures. In the two cultures containing calcitonin-responsive cells heparin inhibited the cyclic AMP response induced by calcitonin. Heparin did not affect the cyclic AMP response to parathyroid hormone or prostaglandin $\mathrm{E}_{2}$. Heparin also increased the cyclic AMP content of cultured adherent rheumatoid synovial cells. It is proposed that, in certain situations of focal pathological bone resorption, although concentrations of circulating hormones may be normal, the local release of products such as heparin may modify the effect of hormones which regulate connective tissue homoeostasis. Local changes in hormone responses could contribute to the enhanced bone resorption associated with inflammatory processes such as rheumatoid arthritis.

The biological activities of bone cells are regulated by many different factors including specific ligands, some of which are produced locally, and others, for example, calcitonin and parathyroid hormone, which arrive via the circulation. It is likely that the skeletal tissue cells involved in pathological resorption of bone adjacent to the rheumatoid pannus would also be subject to functional modulation by circulating and locally produced ligands. Soluble products released by the pannus or cellular interactions occurring between the pannus and adjacent skeletal tissue could result in localised alterations in responses of bone cells to hormones. Modulation of responses to the hormones which regulate skeletal tissue homoeostasis could contribute to the focal

Accepted for publication 26 January 1984.

This is publication 945 of the Lovett Memorial Group for the Study of Crippling Diseases.

This work was presented in part at the Heberden Society Annual Meeting, London, in November 1983.

Correspondence to Dr A. J. Crisp, Rheumatology Research Unit, Addenbrooke's Hospital, Hills Road, Cambridge CB2 2QQ, England. bone destruction which characterises the rheumatoid lesion.

Serum levels of parathyroid hormone are normal in patients with rheumatoid arthritis. ${ }^{12}$ Although serum calcitonin levels have been reported to be reduced, ${ }^{2}$ there is no direct evidence that these low levels contribute to the bone destruction which occurs in patients with rheumatoid disease. We have recently reported that cells cultured from rheumatoid synovium respond to parathyroid hormone and prostaglandin $\mathrm{E}_{2}$ (but not calcitonin) with an increase in cyclic AMP content. ${ }^{3}$ We have also shown that prostaglandins released by rheumatoid tissue may alter sensitivity to parathyroid hormone. ${ }^{3}$ It is likely that other soluble products produced by the pannus may also modify hormone responses. For example, increased numbers of mast cells have been found in the joints of patients with rheumatoid arthritis. ${ }^{4}$ The proximity of these cells to regions of connective tissue resorption suggests that mast cells might participate in the erosion of cartilage ${ }^{5}$ and of bone. ${ }^{4}$ Heparin glycosaminoglycan is found solely in mast cells or extruded mast cell granules, ${ }^{6}$ and various preparations of heparin have been shown to 
promote bone resorption in vivo ${ }^{7}$ and in vitro. ${ }^{8}$ The similarity between local erosive hyperparathyroid bone disease and rheumatoid arthritis has been described. ${ }^{9-11}$ Furthermore, parathyroidectomy may cause rheumatoid erosions to regress when hyperparathyroidism coexists with rheumatoid arthritis. ${ }^{12}$ These observations suggest that rheumatoid erosive disease is subject to hormonal modulation. The present study was therefore designed to test the hypothesis that mast-cell-derived heparin may modify the response of bone and synovial cells to circulating hormones. Our studies show that heparin increases cyclic AMP content in bone-derived and rheumatoid synovial cells. In addition heparin selectively inhibits the cyclic AMP response to calcitonin.

\section{Materials and methods}

All culture media and other solutions used for tissue culture were obtained from Grand Island Biological Company (Grand Island, New York). Fetal calf serum was purchased from Microbiological Associates (Walkersville, Maryland), and multiwell tissue culture trays (Costar) from Data Packing Corporation (Cambridge, Massachusetts). Materials used in the cyclic AMP assay were obtained from New England Nuclear (Boston, Massachusetts). Preservative-free porcine intestinal mucosal heparin, obtained from Abbott Laboratories (North Chicago, Illinois), was used in cultures $1-5$ and 8 . This product subsequently became unavailable, and the similar product provided by Sigma (St Louis, Missouri) was used in cultures 6 and 7. The phosphodiesterase inhibitor, 3-isobutyl-1-1-methylxanthine (IBMX) was purchased from Aldrich (Milwaukee, Wisconsin).
Test solutions of hormones were prepared by dissolving in incubation buffer lyophilised samples of bovine parathyroid hormone (1-84) or salmon calcitonin (Armour, $5000 \mathrm{MRC}$ units/mg) provided by Dr Henry T. Keutmann, Massachusetts General Hospital. Prostaglandin $E_{2}$ was a gift from Upjohn, Kalamazoo, Michigan. Cell counts were performed throughout by Coulter counter.

Human trabecular bone culture. Human trabecular bone was obtained from eight patients detailed in Table 1. Five specimens were obtained from patients with rheumatoid arthritis at sites adjacent to involved joints. Single specimens were obtained from a patient at necropsy with no apparent joint disease and from patients with Paget's disease and cleidocranial dysostosis. Cortical bone and cartilage were excised from these specimens leaving blocks of trabecular bone uncontaminated by non-osseous soft tissue. Blocks were divided into 1-2 mm long fragments which were washed in three changes of phosphate buffered saline. Fragments were placed in $6 \mathrm{~cm}$ or $10 \mathrm{~cm}$ diameter culture plates (Falcon) in Dulbecco's modified Eagle's medium containing $10 \%(\mathrm{v} / \mathrm{v})$ fetal calf serum, $100 \mathrm{units} / \mathrm{ml}$ penicillin, and $100 \mu \mathrm{g} / \mathrm{ml}$ streptomycin. They were incubated at $37^{\circ} \mathrm{C}$ in an atmosphere of $\mathrm{CO}_{2}$ in air $(1: 20, \mathrm{v} / \mathrm{v})$. By 7 days cellular and matrix outgrowths were visible, and by 14 days cells adherent to the culture plates were found. Plates were confluent by $30-36$ days. Cells from six cultures were stained for the presence of alkaline and acid phosphatase, markers of osteoblasts and osteoclasts respectively. Between $10-80 \%$ of cells contained alkaline phosphatase activity (Fig. 1) (Table 1). Cells from cultures $2-5$ were stained at third passage and cells from cultures 6 and 7 were stained at second passage. Some negatively stained

Table 1 Effects of heparin on cyclic AMP content of human trabecular bone cells

\begin{tabular}{|c|c|c|c|c|c|c|}
\hline \multirow[t]{2}{*}{ Culture number } & \multirow[t]{2}{*}{ Origin of bone } & \multirow{2}{*}{$\begin{array}{l}\% \text { cells stained } \\
\text { for alkaline } \\
\text { phosphatase }\end{array}$} & \multirow{2}{*}{$\begin{array}{l}\text { Passage } \\
\text { number }\end{array}$} & \multicolumn{3}{|c|}{ Cyclic $A M P\left(\right.$ picomoles $/ 1 \times 10^{5}$ cells $)$} \\
\hline & & & & Buffer & $\begin{array}{l}\text { Heparin } \\
(1 \mathrm{mg} / \mathrm{ml})\end{array}$ & Fold change \\
\hline 1 & Normal metatarsal & - & 2 & $7 \cdot 24 \pm 3 \cdot 21$ & $18 \cdot 05 \pm 4 \cdot 34$ & $+2 \cdot 5$ \\
\hline 2 & Metacarpal & 50 & 1 & $2 \cdot 12 \pm 0 \cdot 64$ & $1 \cdot 27 \pm 0 \cdot 28$ & $-0 \cdot 6$ \\
\hline 3 & Metacarpal & 40 & 1 & $1 \cdot 46 \pm 0 \cdot 96$ & $3 \cdot 49 \pm 0 \cdot 72$ & $+2 \cdot 3$ \\
\hline 4 & Distal ulna & 10 & 2 & $1 \cdot 61 \pm 0 \cdot 51$ & $3 \cdot 73 \pm 0 \cdot 51$ & $+2 \cdot 3$ \\
\hline 5 & Distal ulna & 10 & 2 & $3 \cdot 02 \pm 0 \cdot 21$ & $4.97 \pm 0 \cdot 39$ & $+1 \cdot 7$ \\
\hline 6 & Distal ulna & 80 & 1 & $13 \cdot 72 \pm 2 \cdot 90$ & $25 \cdot 38 \pm 2 \cdot 65$ & +1.9 \\
\hline 7 & Femoral head & 40 & 1 & $19 \cdot 31 \pm 1 \cdot 73$ & $38 \cdot 02 \pm 3 \cdot 04$ & $+2 \cdot 0$ \\
\hline 8 & Iliac crest & - & 2 & $1.75 \pm 0.73$ & $5 \cdot 22 \pm 1 \cdot 38$ & $+2 \cdot 9$ \\
\hline
\end{tabular}

Bone specimens 2-6 were obtained from sites adjacent to joints involved by rheumatoid arthritis. Specimen 7 was from bone involved by Paget's disease. Specimen 8 was from uninvolved bone in a patient with clcidocranial dysostosis. Cells from cultures $2-5$ were staincd for alkaline phosphatase at third passage and cells from cultures 6 and 7 were stained at second passage. Intracellular cyclic AMP (picomoles $/ 1 \times 10^{5}$ cells) is expressed \pm standard error of the mean of triplicate samples. The differences between paired samples are significant at $\mathrm{p}<0.05$.

SI conversion $=\mathrm{mg} / \mathrm{ml} \times 1000=\mathrm{mg} / \mathrm{l}$. 


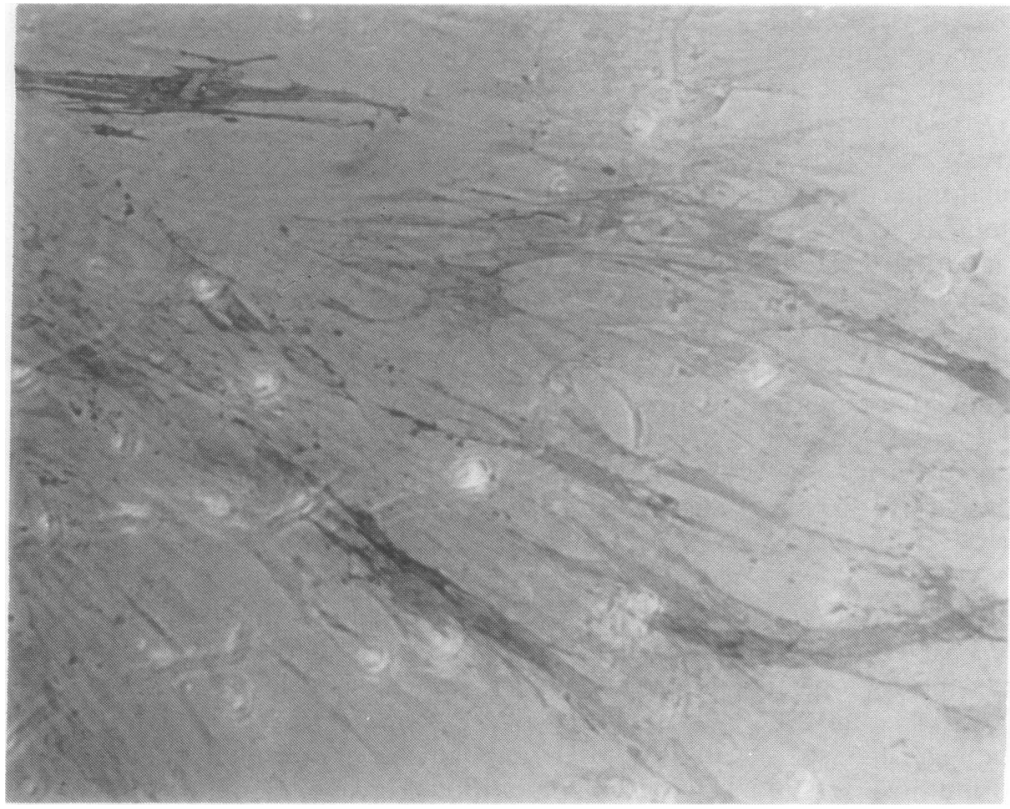

Fig. 1 Cells derived from human trabecular bone explants in culture showing the flattened multipolar morphology of the cells stained positively for alkaline phosphatase activity. (Phase contrast micrograph, $\times 280$ cells possessed a flattened, multipolar morphology similar to that of cells stained positively for alkaline phosphatase activity, and other cells had typical fibroblast-like features. It is conceivable that cultures also contained cells of endothelial origin. About $5 \%$ of cells in culture 4 contained tartrateresistant acid phosphatase.

Adherent rheumatoid synovial cell culture. Cultures of adherent synovial cells were prepared by dispersing cells with proteolytic enzymes as described previously. ${ }^{13}$

Incubations of cells with hormones and heparin. Bone and synovial cells between first and third passages were treated with trypsin $(0.05 \%, w / v)$ EDTA $(0.02 \%, w / v)$ and passed into multiwell trays at concentrations of $0.5-1.0 \times 10^{5}$ cells/well. Between 48 and 72 hours later cells were washed gently with phosphate buffered saline containing $0.9 \mathrm{mM}$ calcium and $0.5 \mathrm{mM}$ magnesium. They were then incubated at $37^{\circ} \mathrm{C}$ with test substances in a buffer solution consisting of phosphate buffered saline, 0.9 $\mathrm{mM}$ calcium, $0.5 \mathrm{mM}$ magnesium, $0.25 \%$ (w/v) bovine serum albumin, $0 \cdot 1 \%(\mathrm{w} / \mathrm{v})$ glucose, and the phosphodiesterase inhibitor, IBMX $1 \mathrm{mM}$, to inhibit cyclic AMP degradation. Incubations were for 20 minutes except in the time-course experiments. The reactions were stopped by immersing the trays in liquid nitrogen.

Assay of cyclic AMP. Multiwell trays were thawed by suspension in a boiling water bath and contents brought to dryness. $1 \mathrm{ml}$ of $0.05 \mathrm{M}$ sodium acetate buffer, adjusted to $\mathrm{pH} 6 \cdot 2$, was added to each well and the contents scraped with a plastic policeman and then transferred to glass tubes. After centrifugation at $2^{\circ} \mathrm{C}$ at $3000 \mathrm{rpm}$ for 10 minutes $50 \mu \mathrm{l}$ of supernatant was removed for estimation of cyclic AMP. A radioimmunoassay employing an 18-hour incubation at $2^{\circ} \mathrm{C}$ of test sample, $\left({ }^{125} \mathrm{I}\right)$-labelled cyclic AMP, anticyclic AMP serum, with an acetylation step to increase sensitivity, was used. ${ }^{14} \mathrm{~A}$ standard curve was obtained by linear regression analysis of the data and test values were read directly from the curve.

Statistical analysis of results was by Student's $t$ tests.

\section{Results}

Effect of heparin on human trabecular bone cells. The effect of heparin, $1 \mathrm{mg} / \mathrm{ml}$ (approximately $10^{-4} \mathrm{M}$ ), on the content of cyclic AMP in human trabecular bone cells is shown in Table 1. Heparin increased cyclic AMP content by an average of approximately 2 -fold in seven out of eight cultures. The difference between paired samples is significant at $p<0 \cdot 05$. Although it is not possible to compare adequately the cyclic AMP content of cells from different cultures, the highest unstimulated and stimulated content was found in cells cultured from a femoral head involved by Paget's disease. It is probably coincidental that the highest cyclic AMP values were found in cultures 6 and 7 , in which heparin purchased from Sigma was used, as control values were also raised proportionally, representing 
a consistent approximately 2 -fold stimulation by both preparations of heparin. Heparin stimulated bone cell cyclic AMP content in a dose-dependent manner between $0.025 \mathrm{mg} / \mathrm{ml}\left(2 \times 10^{-6} \mathrm{M}\right)$ and 2 $\mathrm{mg} / \mathrm{ml}\left(2 \times 10^{-4} \mathrm{M}\right)$ after a 20 -minute incubation

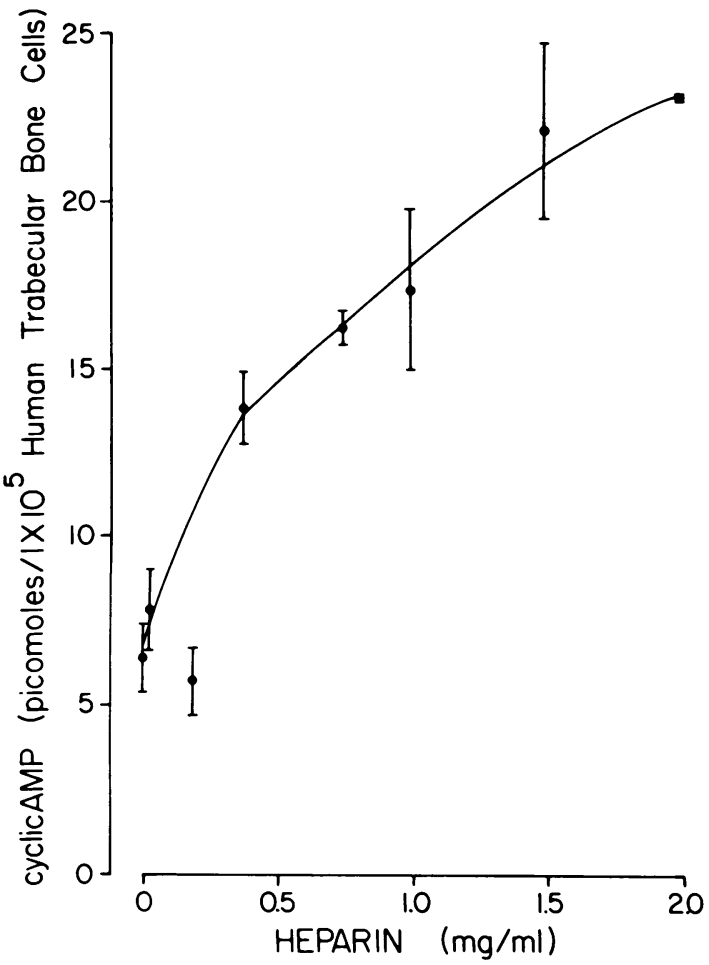

Fig. 2 The dose-dependent effect of heparin on the content of cyclic AMP of human trabecular bone cells (culture 8 in passage 3) after a 20-minute incubation. Intracellular content of cyclic AMP is expressed in picomoles $/ 1 \times 10^{5}$ cells \pm standard error of the mean of triplicates.
(Fig. 2). In a time course experiment employing heparin, $1 \mathrm{mg} / \mathrm{ml}$, a biphasic pattern of cyclic AMP content was observed. These changes occurred in cells incubated in buffer alone and in heparin (Fig. 3 ). A peak stimulation of approximately $2 \cdot 5$-fold was observed at 5-10 minutes followed by a nadir at 20 minutes and then a gradual increase in cyclic AMP levels. (SI conversion: $\mathrm{mg} / \mathrm{ml} \times 1000=\mathrm{mg} / \mathrm{l}$ ).

Effects of hormones and their interactions with heparin on trabecular bone cells. Parathyroid hor-

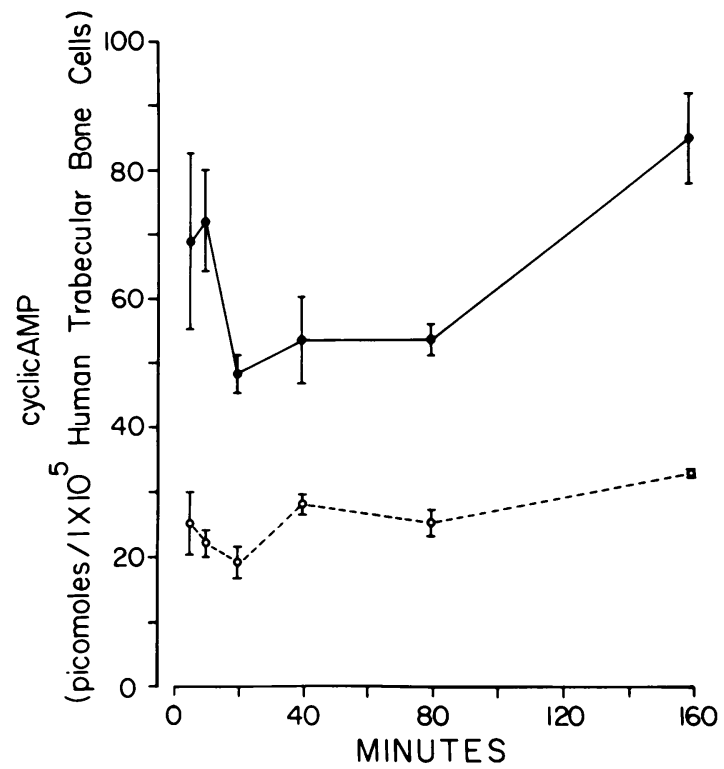

Fig. 3 The intracellular content of cyclic AMP in human trabecular bone cells (culture 8 in passage 4) exposed to heparin, $1 \mathrm{mg} / \mathrm{ml}$ (closed circles) and buffer alone (open circles), for time periods between 5 and 160 minutes. Cyclic AMP is expressed in picomoles $/ 1 \times 10^{5}$ cells \pm standard error of the mean of triplicates.

Table 2 Effects of parathyroid hormone and prostaglandin $E_{2}$ on cyclic AMP content of human trabecular bone cells

\begin{tabular}{|c|c|c|c|c|c|}
\hline \multirow[t]{2}{*}{ Culture number } & \multirow[t]{2}{*}{ Buffer } & \multicolumn{4}{|c|}{ Cyclic AMP (picomoles $/ I \times 10^{5}$ cells $)$} \\
\hline & & PTH $(l \mu g / m l)$ & $p$ value & $P G E_{2}(I \mu g / m l)$ & $p$ value \\
\hline 1 & $7 \cdot 24 \pm 3 \cdot 21$ & $36 \cdot 84 \pm 3 \cdot 35$ & $<() \cdot() 1$ & $329 \cdot 64 \pm 18 \cdot 56$ & $<0 \cdot(0) 1$ \\
\hline 2 & $2 \cdot 12 \pm 0 \cdot 64$ & $4 \cdot 00 \pm 1 \cdot 33$ & NS & $135 \cdot 41 \pm 5 \cdot 75$ & $<0 .(0) 1$ \\
\hline 3 & $1.46 \pm 0.96$ & $1.93 \pm 0 \cdot 60$ & NS & $132 \cdot 10 \pm 6 \cdot 77$ & $<0 \cdot(0) 1$ \\
\hline 4 & $1 \cdot 61 \pm 0) \cdot 51$ & $2 \cdot 32 \pm 0.71$ & NS & $55 \cdot 52 \pm 1 \cdot 80$ & $<0 \cdot(0) 1$ \\
\hline 5 & $3 \cdot(02 \pm 0 \cdot 21$ & $1.91 \pm 0.05$ & $<0 \cdot(1) 2$ & $133.34 \pm 10 \cdot 35$ & $<0 \cdot(00) 1$ \\
\hline 6 & $13 \cdot 72 \pm 2 \cdot 90$ & $26 \cdot 12 \pm 3 \cdot 39$ & $<0.05$ & 29()$\cdot 77 \pm 25 \cdot(199$ & $<0 \cdot(0) 1$ \\
\hline 7 & $19 \cdot 31 \pm 1 \cdot 73$ & $46 \cdot 21 \pm 3 \cdot 55$ & $<0 \cdot(0) 1$ & $202 \cdot 06 \pm 3 \cdot 61$ & $<0 \cdot(0) 1$ \\
\hline 8 & $1.75 \pm 0.73$ & $5 \cdot 14 \pm 1 \cdot 65$ & $<0.05$ & $149 \cdot 82 \pm 4 \cdot 54$ & $<0 \cdot(x) 1$ \\
\hline
\end{tabular}

The effects of parathyroid hormone $(\mathrm{PTH}) 1 \mu \mathrm{g} / \mathrm{ml}$ and prostaglandin $\mathrm{E}_{2}\left(\mathrm{PGE}_{2}\right), 1 \mu \mathrm{g} / \mathrm{ml}$, on the same human trabecular bone cell cultures described in Table 1. Intracellular cyclic AMP (picomoles $/ 1 \times 10^{5}$ cells) is expressed \pm standard error of the mean of triplicates. SI conversion: $\mu \mathrm{g} / \mathrm{ml}=\mathrm{mg} / \mathrm{l}$. 
mone, $1 \mu \mathrm{g} / \mathrm{ml}$, raised cyclic AMP content in four out of eight cultures between 2- and 5-fold and apparently decreased it in one culture (Table 2). Prostaglandin $E_{2}, 1 \mu \mathrm{g} / \mathrm{ml}$, stimulated cyclic AMP content between 10- and 90 -fold in all eight cultures (Table 2). In cultures 1 and 4 salmon calcitonin, 1 $\mu \mathrm{g} / \mathrm{ml}$, raised cyclic AMP content 6-fold (Fig. 4). Incubation of these cultures containing calcitoninresponsive cells with calcitonin, $1 \mu \mathrm{g} / \mathrm{ml}$, and heparin, $1 \mathrm{mg} / \mathrm{ml}$, abolished the calcitonin-mediated rise

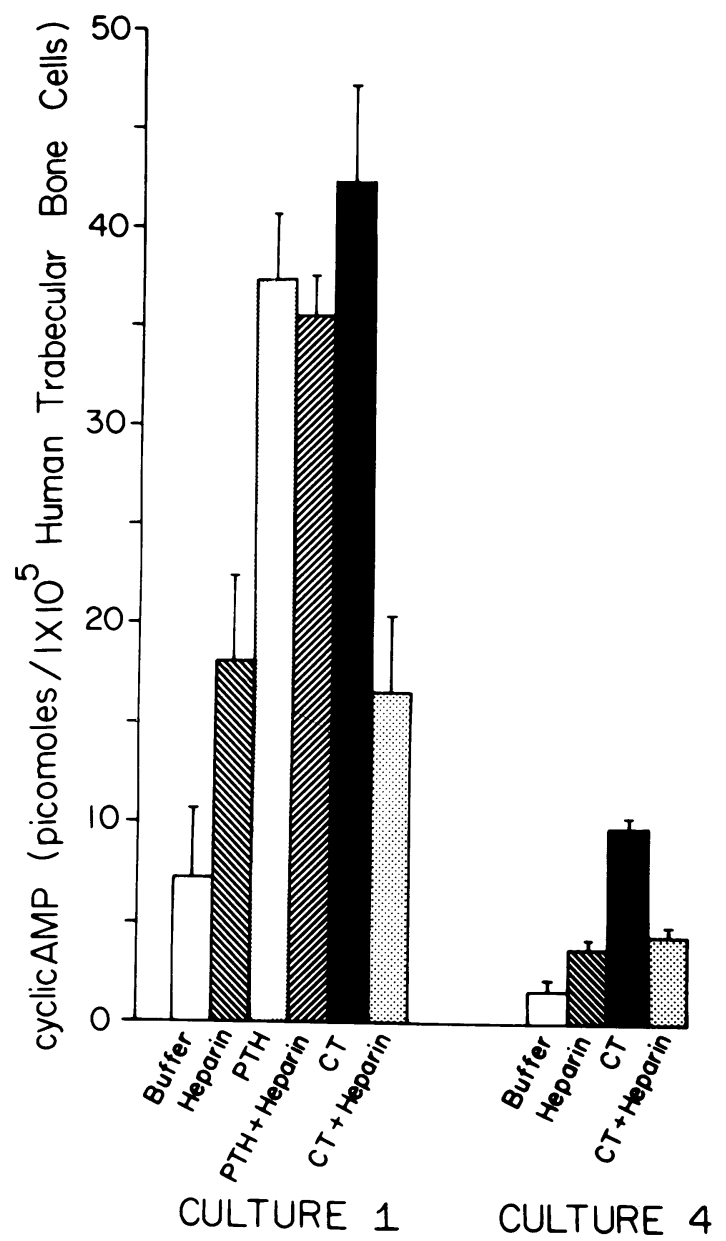

Fig. 4 The intracellular content of cyclic AMP in two cultures of human trabecular bone cells exposed to buffer, heparin $1 \mathrm{mg} / \mathrm{ml}$, parathyroid hormone (PTH) $1 \mathrm{\mu g} / \mathrm{ml}$, parathyroid hormone $1 \mu \mathrm{g} / \mathrm{ml}$ plus heparin $1 \mathrm{mg} / \mathrm{ml}$, salmon calcitonin (CT) $1 \mu \mathrm{g} / \mathrm{ml}$, and salmon calcitonin $1 \mu \mathrm{g} / \mathrm{ml} \mathrm{plus}$ heparin $1 \mathrm{mg} / \mathrm{ml}$. Heparin inhibited the calcitonin-induced rise in cyclic AMP in both cultures but did not inhibit the parathyroid-hormone-induced rise in culture 1. Parathyroid hormone did not raise cyclic AMP above buffer values in culture 4. in cyclic AMP leaving the 2-fold increase induced by heparin alone. (SI conversion: $\mu \mathrm{g} / \mathrm{ml}=\mathrm{mg} / \mathrm{l}$ ).

To determine whether the inhibition of the calcitonin-induced cyclic AMP response by heparin was specific for this hormone cells were incubated with parathyroid hormone in the presence of heparin. As shown in Fig. 4, in culture 1 parathyroid hormone, $1 \mu \mathrm{g} / \mathrm{ml}$, produced a 5 -fold increase of cyclic AMP levels to $37.6 \pm 3.42$ picomoles $/ 1 \times 10^{5}$ cells. Coincubation with heparin, $1 \mathrm{mg} / \mathrm{ml}$, did not alter the parathyroid-hormone-induced increase in cyclic AMP content $\left(35.43 \pm 2 \cdot 01\right.$ picomoles $/ 1 \times 10^{5}$ cells). The effect of heparin on prostaglandin $\mathrm{E}_{2}$-induced cyclic AMP response was tested in two additional cultures, and no effect was observed (data not shown).

Effect of heparin on synovial cells. As was observed in the bone cells, incubation of rheumatoid synovial cells with heparin produced a dosedependent increase in cyclic AMP content (Fig. 5). Maximal increases in cyclic AMP levels were detected with heparin, $1 \mathrm{mg} / \mathrm{ml}$. As observed in the bone-derived cells, time course experiments em-

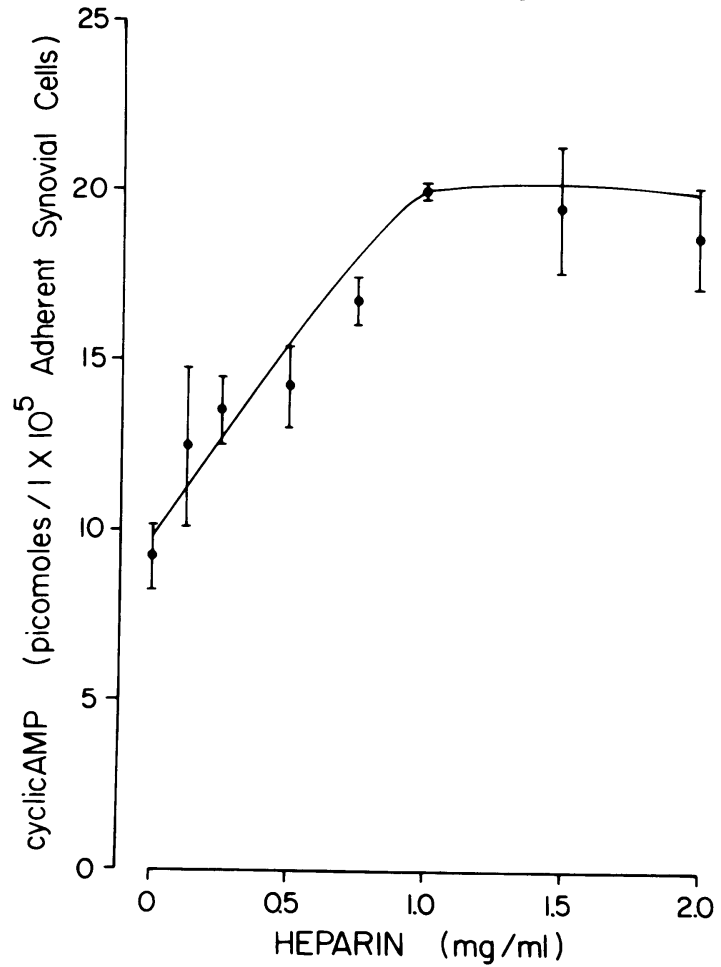

Fig. 5 The dose-dependent effect of heparin on the content of cyclic AMP of adherent rheumatoid synovial cells after $a$ 20-minute incubation. Cyclic AMP is expressed in picomoles $/ I \times 10^{5}$ cells \pm standard error of the mean of triplicates. 
ploying heparin $1 \mathrm{mg} / \mathrm{ml}$ demonstrated a biphasic pattern of changes in cyclic AMP levels.

\section{Discussion}

The chronic administration of heparin in high doses to man has been associated with severe osteopenia. ${ }^{7}$ A similar effect of heparin on enhancing bone resorption has been observed in vitro. Goldhaber, ${ }^{8}$ employing a mouse calvarial organ culture system, demonstrated that heparin increased bone resorption by potentiating the effects of parathyroid hormone. Our studies were designed to explore the effects of heparin on human trabecular bone cells and to investigate specifically the effects of this mast cell product on the response of the target cells to hormones which are known to regulate skeletal tissue homoeostasis.

To study the effects of heparin on cells of skeletal origin we have cultured cells from human bone. An early feature of trabecular bone explants was active cellular activity at the surfaces of the explant which preceded the appearance of bone-derived cells adherent to the plate. Examination with phase contrast microscopy revealed that these surface cells appeared to be synthesising an extracellular matrix, consistent with the proposal that osteoblast-like cells were cultured by this method. ${ }^{15}$ The presence of a cyclic AMP response to parathyroid hormone in four out of our eight bone cell cultures further suggests that the outgrowth cells express osteoblast phenotype. ${ }^{15}$ These cells also show strongly positive staining for alkaline phosphatase ${ }^{16}{ }^{17}$ which - with parathyroid hormone responsiveness - has been considered a marker of osteoblast-like cells isolated from non-human skeletal tissues. ${ }^{18}$

We observed that heparin glycosaminoglycan increased the intracellular content of cyclic AMP in a dose-dependent manner in cultured human trabecular bone cells. The interactions of calcitonin, parathyroid hormone, and prostaglandins with their cell surface receptors are accompanied by activation of adenylate cyclase and rises in intracellular cyclic AMP, and at least some of the biological effects of these hormones are probably mediated by changes in levels of this cyclic nucleotide. It is therefore possible that heparin could have effects on the skeleton by producing increases in the cellular content of cyclic AMP.

In Goldhaber's studies ${ }^{8}$ it appeared that heparin increased bone resorption by augmenting parathyroid-hormone-stimulated resorption. Although heparin itself increased cellular content of cyclic AMP in our cultures of osteoblast-like cells, there was no evidence that heparin potentiated the magnitude of the cyclic AMP response to para- thyroid hormone. An additive, but statistically not significant, effect of heparin on the parathyroidhormone-induced response was occasionally noted.

In two bone cell cultures heparin inhibited the calcitonin-induced rise in cyclic AMP without affecting the parathyroid-hormone-mediated rise in the single culture in which both hormones elevated the cyclic AMP content. If the preliminary data provided by these two bone cell cultures are confirmed, a model may be proposed in which heparin removes the inhibition of osteoclast function imposed by circulating calcitonin and permits the unopposed resorbing action of parathyroid hormone, $1,25(\mathrm{OH})_{2}$ vitamin $\mathrm{D}_{3}$, prostaglandin $\mathrm{E}_{2}$, or osteoclast activating factor. It is possible that cellular responses to parathyroid hormone have already been 'primed' by heparin. In man it remains to be proved, however, that endogenous calcitonin has any physiological function in the regulation of bone turnover.

There are precedents for an inhibitory role of heparin on hormone action. Heparin has been shown to inhibit luteinising-hormone-stimulated ovarian adenylate cyclase. ${ }^{19}$ Dextran sulphate, the polyanion analogue of heparin, inhibits adenylate cyclase in bovine thyroid preparations. ${ }^{20}$ The mechanism of inhibition is unknown. Wolff and $\mathrm{Cook}^{20}$ considered the possibility that the large negative charge of these polyelectrolytes could alter cell membrane function. Structural features other than ionic charge could be important, since the equally negatively charged polyglutamic acid was only slightly inhibitory of ovarian adenylate cyclase. ${ }^{19}$ It has recently been shown that heparin can suppress the cumulus cell-oocyte complex expansion in mice which is mediated by follicle stimulating hormone but does not do so by the inhibition of cyclic AMP production. ${ }^{21}$

We also report that heparin increases intracellular cyclic AMP content in adherent rheumatoid synovial cells. We have demonstrated that these cells produce large amounts of prostaglandin $E_{2}$ and collagenase, ${ }^{22}{ }^{23}$ products implicated in pathological bone resorption. The possible role of cyclic AMP in modulating release of these products is not known. Although we have demonstrated that parathyroid hormone increases cyclic AMP content in synovial cells, we have not so far detected effects of this hormone on prostaglandin or collagenase production (Goldring SR, Dayer JM, Krane SM, personal communication). The framework of mast cell granules is the metachromatic-staining heparin proteoglycan, and it has been recently reported that rat fibroblasts which ingest extruded mast cell granules increase their own production of collagenase. ${ }^{24}$ It is possible that this could be mediated by cyclic AMP 
in the light of reports that cyclic AMP production may influence other secretory functions of human monocytes. ${ }^{25}$ We have not yet assayed the effects of heparin on collagenase production by synovial cells.

An increase in cyclic AMP content of bone and synovial cells exposed to heparin was observed within 5-10 minutes followed by a later further increase. It is likely that the early peak of production at 5-10 minutes is associated with cellular effects of cyclic AMP such as activation of protein kinase. ${ }^{26}$ Cells were routinely incubated with heparin and hormones for 20 minutes, which may have resulted in underestimation of the effect of heparin on intracellular cyclic AMP production. It is not possible to assess the concentrations of heparin likely to be achieved within the microenvironment of mast cell and adjacent bone surface, but this underestimate of heparin effect suggests that heparin may exert an effect at lower concentrations than the $2 \times 10^{-6}-2 \times 10^{-4} \mathrm{M}$ employed in these experiments. Although the phosphodiesterase inhibitor, IBMX, was present in these experiments, it is known that even in high concentrations this compound does not completely inhibit intracellular phosphodiesterase activity. Therefore it is possible that the heparin-induced changes in cyclic AMP levels could be related to effects on phosphodiesterase activity rather than the adenylate cyclase enzyme complex. ${ }^{27}$

We have recently reported the presence of increased numbers of mast cells in the rheumatoid pannus and in bone erosions characterised by osteoclastic bone resorption. ${ }^{4}$ These observations suggest a possible role for heparin in pathological bone resorption. The demonstration that heparin increases basal cyclic AMP levels and modulates hormone responsiveness in trabecular bone cells and adherent rheumatoid synovial cells provides a potential mechanism of action for this mast cell product in the bone destruction associated with the rheumatoid pannus.

This work was supported by USPHS grants AM-03564 and AM-07258. A.J.C. was a Travelling Fellow of the Arthritis and Rheumatism Council of the United Kingdom and also acknowledges the support of the King Edward's Hospital Fund for London and of the Wellcome Trust.

\section{References}

1 Kennedy A C, Allam B F, Rooney P J, et al. Hypercalcaemia in rheumatoid arthritis: an investigation of its causes and implications. Ann Rheum Dis 1979; 38: 401-12.

2 Orth R W, Weisman M H, Catherwood B D, Manolagas S C, Deftos L J. Bone loss in rheumatoid arthritis. Arthritis Rheum 1983; 26 (suppl.): S25.

3 Goldring S R, Dayer J-M, Krane S M. Hormone responses modulated by cell-cell interactions. Inflammation in press.

4 Crisp A J, Chapman C M, Kirkham S E, Schiller A L, Krane S M. Articular mastocytosis in rheumatoid arthritis. Arthritis Rheum in press.
5 Bromley M, Fisher W D, Woolley D E. Mast cells at sites of cartilage erosion in the rheumatoid joint. Ann Rheum Dis 1984; 43: 76-9.

6 Straus A H, Nader H B, Dietrich C P. Absence of heparin or heparin-like compounds in mast cell-free tissues and animals. Biochim Biophys Acta 1982; 717: 478-85.

7 Avioli L V. Heparin-induced osteopenia: an appraisal. $A d v$ Exp Med Biol 1975; 52: 375-87.

8 Goldhaber P. Heparin enhancement of factors stimulating bone resorption in tissue culture. Science 1965; 147: 407-9.

9 Zvaifler N J, Reefe W E, Black R L. Articular manifestations in primary hyperparathyroidism. Arthritis Rheum 1962; 5: 237-49.

10 Bywaters E G L, Dixon A St J, Scott J T. Joint lesions of hyperparathyroidism. Ann Rheum Dis 1963; 22: 171-87.

11 Resnick D. Erosive arthritis of the hand and wrist in hyperparathyroidism. Radiology 1974; 110: 263-9.

12 Crisp A J, Helliwell M, Grahame R. The effect of primary hyperparathyroidism on the course of rheumatoid arthritis. $\mathrm{BrJ}$ Rheumatol 1983; 22: 22-8.

13 Dayer J M, Krane S M, Russell R G G, Robinson D R. Production of collagenase and prostaglandins by isolated adherent rheumatoid synovial cells. Proc Natl Acad Sci USA 1976; 73: 945-9.

14 Goldring S R, Dayer J M, Russell R G G, Mankin H J, Krane $\mathrm{S} \mathrm{M}$. Response to hormones of cells cultured from giant cell tumors of bone. J Clin Endocrinol Metab 1978; 46: 425-33.

15 Beresford J N, MacDonald B R, Gowen M, et al. Further characterization of a system for the culture of human bone cells Calcif Tiss Int 1983; 35: 637

16 Wergedal J E, Baylink D J. Distribution of acid and alkaline phosphatase activity in undemineralized sections of the rat diaphysis. J Histochem Cytochem 1969; 17: 799-806.

17 Crisp A J, McGuire-Goldring M B, Goldring S R. A system for culture of human trabecular bone and hormone response profiles of derived cells. Submitted for publication.

18 Yee J A. Properties of osteoblast-like cells isolated from the cortical endosteal bone surface of adult rabbits. Calcif Tiss Int 1983; 35: 571-7.

19 Salomon Y, Amsterdam A. Heparin: a potent inhibitor of ovarian luteinizing hormone-sensitive adenylate cyclase. FEBS Lett 1977; 83: 263-6.

20 Wolff $\mathrm{J}$, Cook $\mathrm{G} \mathrm{H}$. Charge effects in the activation of adenylate cyclase. J Biol Chem 1975; 250: 6897-903.

21 Eppig J J, Ward Bailey P F, Potter J E, Schultz R M. Differential action of sulfated glycosaminoglycans on folliclestimulating hormone-induced functions of cumuli oophori isolated from mice. Biol Reprod 1982; 27: 388-406.

22 Dayer J M, Robinson D R, Krane S M. Prostaglandin production by rheumatoid synovial cells: stimulation by a factor from human mononuclear cells. J Exp Med 1977; 145: 1399 404.

23 Dayer J M, Russell R G G, Krane S M. Collagenase production by rheumatoid synovial cells: stimulation by a human lymphocyte factor. Science 1977; 195: 181-3.

24 Subba Rao P V, Friedman M M, Atkins F M, Metcalfe D D. Phagocytosis of mast cell granules by cultured fibroblasts. $J$ Immunol 1983; 130: 341-9.

25 Passwell J H, Goldring S R, Dayer J M. Effects of concanavalin $A$ and $\mathrm{Fc}$ fragments of IgG on human monocyte cAMP content: modulation of monocyte secretory function by cAMP. Immunology 1982; 46: 415-21.

26 Dufau M L, Tsuruhara T, Horner K A, Podesta E, Catt K J. Intermediate role of adenosine $3^{\prime} 5^{\prime}$ cyclic monophosphate and protein kinase during gonadotrophin-induced steroidogenesis in testicular interstitial cells. Proc Natl Acad Sci USA 1977; 74: 3419-23.

27 Strada S J, Thompson W J. Multiple forms of phosphodiesterases: anomalies or biologic regulators? Adv Cyclic Nucleotide Res 1978; 9: 265-83. 